Article

\title{
Smart and Resilient Urban Futures for Sustainability in the Post COVID-19 Era: A Review of Policy Responses on Urban Mobility
}

\author{
Christina Kakderi *, Eleni Oikonomaki and Ilektra Papadaki
}

check for updates

Citation: Kakderi, C.; Oikonomaki, E.; Papadaki, I. Smart and Resilient Urban Futures for Sustainability in the Post COVID-19 Era: A Review of Policy Responses on Urban Mobility. Sustainability 2021, 13, 6486.

https://doi.org/10.3390/su13116486

Academic Editor: Andrew Kirby

Received: 5 April 2021

Accepted: 31 May 2021

Published: 7 June 2021

Publisher's Note: MDPI stays neutral with regard to jurisdictional claims in published maps and institutional affiliations.

Copyright: (c) 2021 by the authors. Licensee MDPI, Basel, Switzerland. This article is an open access article distributed under the terms and conditions of the Creative Commons Attribution (CC BY) license (https:/ / creativecommons.org/licenses/by/ $4.0 /)$.
URENIO Research, Aristotle University of Thessaloniki, 54124 Thessaloniki, Greece; Eleni.Oikonomaki@urenio.org (E.O.); Ilektra.Papadaki@urenio.org (I.P.)

* Correspondence: kakderi@plandevel.auth.gr

Abstract: The COVID-19 pandemic has put lifestyles in question, changed daily routines, and limited citizen freedoms that seemed inalienable before. A human activity that has been greatly affected since the beginning of the health crisis is mobility. Focusing on mobility, we aim to discuss the transformational impact that the pandemic brought to this specific urban domain, especially with regards to the promotion of sustainability, the smart growth agenda, and the acceleration towards the smart city paradigm. We collect 60 initial policy responses related to urban mobility from cities around the world and analyze them based on the challenge they aim to address, the exact principles of smart growth and sustainable mobility that they encapsulate, as well as the level of ICT penetration. Our findings suggest that emerging strategies, although mainly temporary, are transformational, in line with the principles of smart growth and sustainable development. Most policy responses adopted during the first months of the pandemic, however, fail to leverage advancements made in the field of smart cities, and to adopt off-the-shelf solutions such as monitoring, alerting, and operations management.

Keywords: urban planning; COVID-19; urban mobility; sustainability; smart cities; smart growth; pandemic; resilience

\section{Introduction}

The world today evolves rapidly facing both unpredictable and long-lasting crises. Climate change and the COVID-19 pandemic challenge the resilience of cities, but also reveal the need to reshape the urban space [1]. Crises urge for quick and efficient recovery planning and crisis management, yet traditional planning mechanisms in most cities are slow and relatively rigid. Crises create emergencies and transformational needs that require more responsive and agile planning, as opposed to traditional urban planning which, as a political, technical, and social process, requires setting long-term growth targets and identifying the conditions for these in terms of potential land-use needs. Crises disrupt the urban environment and urge for transformation of the urban structures not only in terms of the physical space (land use, infrastructure, buildings, etc.), but also in terms of operations and behavior. The concept of resilient urban planning encapsulates a new kind of responsive and flexible planning that considers both the need to accelerate change that leads to recovery and the complexity of urban ecosystems and their various interrelations and systemic interactions [2].

The current global pandemic has profoundly affected major urban centers all over the world [3]. Confinement has put lifestyles in question, changed daily priorities, and limited citizen freedoms that seemed inalienable before. Citizens have finally found the opportunity to consider the environment in which they live and value the importance of key elements that contribute to their health and well-being, such as the quality of air and the availability of open and green space. On the other hand, a new set of rules on social 
interactions and urban operations are fundamentally transforming the way we live, work, and experience public space. These rules can be hardly seen as a temporary condition before going back to normal. The great impact of the crisis, as well as its long duration, has already started to affect human behavior and routines that have been gradually formulated throughout the course of time. These changes are particularly magnified in large cities where the population is concentrated in higher density. In this context, urban planning is facing a major challenge: It has to create a balance between the urban engine of growth that operates through the concentration of talent and social interactions and, at the same time, contain contagions. The outcome of this task will become the new normal.

The new rules of social distancing and the restrictive policies that were adopted in most places around the world had a disruptive impact on the way we live and have reshaped urban mobility. In this setting, two opposite trends emerge, which may be dependent on the specific cultural and economic environment. The first poses new barriers to sustainability with a decline in the demand of public transport and the shift towards individual motorized mobility as a safer alternative $[4,5]$. The second trend leads to an acceleration of sustainable mobility through walking, cycling, and other forms of micromobility, while the actual need for commuting is also reduced due to remote working [6]. Based on these, the role of urban mobility in resilience planning comes again to the front [7].

The responsiveness and resilience of cities against crises is argued to be greatly affected by technology in the sense that it can convey and manage complexities in a meaningful way, improve responsiveness, and create flexible areas for participation and creativity [8,9]. Smart city technologies and applications (e.g., sensors, data analytics, artificial intelligence, IoT, monitoring systems of urban operations, and infrastructure) can improve the efficiency, awareness, preparedness, and flexibility of urban environments through alerts, real-time adjustments, and better decision-making [10]. These applications and technologies also offer new platforms for social interactions (e.g., through social networks and digital platforms) that cultivate networking, collaborative innovation, and behavior adaptation based on a specific problem or need [11-13]. Yet, the type of each crisis and the challenges that it creates may vary significantly from the previous one [14], therefore, with each crisis the value of these technologies must be re-assessed. This is certainly the case with COVID-19, which is a worldwide unprecedented crisis with a detrimental impact on urban life.

With a focus on this specific urban domain, mobility, several questions arise about the short-term and the long-term transformations created in urban settings.

- What kind of policies did cities adopt during the pandemic with regards to urban mobility? How did they respond to the pandemic since the factors of their vulnerability are bound in the built environment itself and the urban planning paradigm which encourages density? (RQ1)

- When the solution to the problem seems to be social distancing, how have urban planners and city authorities adapted to the emerging needs and what was the impact of their actions on urban growth and sustainability? (RQ2)

- In this opportunity for change, what is the role of technology? (RQ3)

We aim to address these questions by investigating 60 different urban mobility policy responses to the COVID-19 crisis in cities across the world. We pursue this by grouping the cities' responses based on the type of challenge they want to address, their timeframe and implementation mode, as well as the level in which they incorporate digital technologies and smart city applications. Our research is at the intersection of urban planning and mobility planning with the evolving concepts of smart and resilient cities, exposing weaknesses in the way smart solutions have penetrated urban land use and mobility planning. The results of the paper fuel the discussion on the transition of urban centers towards more resilient, sustainable, and intelligent spaces.

\section{Covid-19 and the Future of Cities: Three Challenges for Urban Centers}

The COVID-19 pandemic reshaped our world in multiple ways and has dramatically affected people's routines and their everyday life. The spread of the virus has led govern- 
ments to adopt unprecedented measures, including extensive restrictions on travel and commutes, the temporary shutdown of businesses, and the widespread use of teleworking. Among the hardest hit domains, experiencing the most abrupt shock in modern times, is mobility. Using map services such as Google Maps and Apple Maps, or data from companies such as Mapbox and TomTom, we saw a significant decline in urban traffic volume starting from the first few months of 2020 in many cities that traditionally had high levels of traffic $[15,16]$.

Sadly, once the temporary restrictive measures were lifted, people's behavior tended towards their old routines. Therefore, besides many parts of the world being in lockdown for several months and human activities pausing, the earth overshoot day for 2020 was on August 22 [17]. The environmental burden linked to workers being requested to go back to work is very likely to increase for the months to come with the spread of car use, since public transportation is associated with a high risk for contamination. On 30 July 2020, data published by Apple Maps on searches for directions to travel by car show notable increases compared with volumes recorded on 13 January and corresponding to a $16 \%$ rise in the USA and 14\% in Germany. The actual impact of COVID-19 and the future of cities post-pandemic is emerging as a popular topic among scholars from different disciplines, since intrinsic attributes of the urban system itself (high density, mass transport, free use of public space, connectivity, and unrestricted individual mobility) affect the potential success of epidemic prevention and management $[3,18,19]$.

While cities are still struggling to confront the consequences of the health crisis, individual researchers and international organizations are collecting best cases, policy responses, guidance, and recommendations aiming to create a pool of knowledge upon which cities could strategically build their long-term transformation agendas. This is particularly evident in the field of urban mobility. Online platforms and crowdsourcing maps, constantly updated with policy responses from cities all over the world (e.g., COVID Mobility Works, EIT Urban Mobility and Cities for Global Health, the National Association of City Transportation Officials-NACTO, among many others), complement reports on different city actions for recovery and resilience $[20,21]$. The prevalence of each one may lead to alternative scenarios for the future [6]. Despite the exhaustive collection, which may improve cities' level of responsiveness, there is no systematic analysis of policy responses in terms of predefined criteria, as well as with regards to their effect on other major challenges for urban centers. For example, some policy measures seem effective to restrict contagion, increase inequality, or reduce sustainability, whereas others, perhaps less effective, encourage bottom-up participation and the exploitation of ICT technologies and may, therefore, have a wider positive impact on the city. Although it is difficult to assess the long-lasting impact of such measures and the direction in which they may lead us, it is crucial to identify whether these can become the trigger for change towards smarter and more sustainable places for growth.

\subsection{Re-Inventing Urban Planning Through the Lens of Smart Growth and Responsive Planning}

During the last few decades, the population in urban centers has been growing at an unprecedented pace and the reaction of many urban dwellers, architects, and planners, such as Jane Jacobs and Jan Gehl, is that dense compact neighborhoods can enhance social cohesion. Over the last 50 years, numerous land-use planning policies following this approach determined high-density mixed-use development in town centers.

The importance of these priorities was challenged and questioned at the beginning of the COVID-19 crisis. Demographics and mobility patterns showed an exodus out of crowded cities such as New York and San Francisco towards suburbs and smaller cities [22]. Evidence of the association between density and COVID-19 transmission is still contrasting and inconclusive [1], and data analysis has shown that the correlation between urban density and virus spread ignores the comparative experiences of cities. New York and Singapore have a similar density of upwards of 20,000 people per square mile; however, Singapore managed to keep the initial outbreak numbers low in comparison to New York 
City. Nevertheless, it is far more challenging to secure social distancing in high-density cities, especially when the urban design poses additional constraints. A Social Distancing Dashboard created by TU Delft shows that social distancing in Dutch cities is practically impossible due to the physical constraints of the urban environment (width of sidewalk) combined with other variables, e.g., number of residents in the neighborhood, and the typology of places such as bus stops, supermarkets, etc., where people are more likely to concentrate [23].

The pandemic also revealed the lack of proximity to green and open space in urban centers and, especially, less privileged neighborhoods. Access to green space within the allowed displacement limits (in the case of France, this corresponded to a $2 \mathrm{~km}$ radius from the residence during spring 2020) was for many urban dwellers practically impossible. As a result, several academics call for a new paradigm of urbanism that rethinks our transit systems, our green spaces, our city services, and our built environment, and redesigns them considering inequalities.

The provision of flexibility in land-use distribution and the increase of mixed-use environments will eventually enhance the vision of a safe and sustainable city and take into consideration the deep inequalities. In support of that vision, neighborhood planning can enhance the concept of "complete neighborhoods," i.e., compact, walkable neighborhoods that include all the services one needs in a sustainable urban environment (housing, employment, retail, schools, libraries, health centers) within walking distance [24]. By implementing the model of complete neighborhoods, one can retain all the benefits of a big city and bring inclusion and accessibility while reducing the need for long commutes and mass transit.

This has become a goal for many urban policymakers. Such is the example of "the 20-min neighborhood," indicating a planning paradigm with which most residents can fulfill their daily needs and activities within 20 min of walking or cycling. Similar is the concept of the "15-minute city," which was brought up as a key element of the successful re-election campaign of Paris' mayor, Anne Hidalgo. Giving more emphasis to sustainability, we also observe the rise and evolution of the concept of "smart growth," an urban planning paradigm that creates economically prosperous, socially equitable, and environmentally sustainable cities [25]. The smart growth principles, proposed by the Smart Growth Network and also used in the work of Ye et al. [26], include components that are directly linked to urban transport and mobility. They include the pedestrianization of spaces previously allocated to cars, the creation of facilities for cycling and other forms of micromobility, public transit promotion through reduced fees, as well as systems integration and nodal networks.

The abovementioned directions have been further highlighted in the COVID-19 crisis. Scholars, in their analysis of recreational use of green space during the pandemic, highlight the significance of urban green infrastructure for resilient planning [27-29]. Others question the future use of large public spaces as spaces of civic action and foresee their rediscovery with alternative uses [30]. Although the literature is still evolving, many researchers have discussed the need for flexibility in zoning and land-use distribution [19,24], and there is also seminal work on the use of computational techniques to assess alternative post-pandemic urban planning scenarios [31].

\subsection{The Future of Mobility and the Challenges for Urban Public Transport}

The COVID-19 health crisis profoundly impacted public transportation and urban mobility. Moovit [32], a popular transit app, released a public transport index with near real-time public transit data showing a decline in the usage of public transit reaching record low levels in many large cities, immediately after the introduction of mobility restrictions (e.g., 90\% in London, $92 \%$ in Lyon). Public transport ridership has fallen sharply during the lockdown and beyond, due to the widespread use of teleworking and e-learning, as well as the fear of infection (especially in mass transit, which already had the stigma of being "dirty and crowded") [33]. Apart from losing passengers' trust, operators also carried the burden 
of implementing new hygiene protocols (e.g., frequent sanitization of public transportation vehicles and stations) and adopting new rules of operation (e.g., reduction of maximum occupancy) [5]. The fall in demand and the significant financial distress has led to the reduction of services and the restriction of available routes for citizens who increasingly turn towards alternative modes of mobility, such as the use of private cars, shared mobility, and active mobility (cycling and walking). This shift, however, is not possible by all, and the decline in the quality of service in public transportation could marginalize residents of poorer suburbs who have to commute daily to blue-collar jobs that cannot be conducted remotely [34].

The rise of sustainable individual mobility modes such as walking and cycling is impressive: In the UK, bicycle sales in the first months of 2020 increased by $63 \%$ and the traffic in the bike lanes of Paris rose by $29 \%$ on average [35-38]. This also accelerated government-led changes and investments towards sustainability, such as the European Green Deal (the European Green Deal is a new growth strategy that aims to transform the EU into a fair and prosperous society, with a modern, resource-efficient, and competitive economy where there are no net emissions of greenhouse gases by 2050 and where economic growth is decoupled from resource use) [39]. On the other side of the Atlantic, economists, academics, and policymakers have presented the COVID-19 pandemic as an opportunity to fix the American economy and the planet for the long term by including the Green New Deal, or parts of it, in the recovery program in the US [40]. For the moment, though, it is unclear whether these trends and changes will remain in the long term and what the final output on the environment will be [41]. China and Spain, among other countries, are providing incentives for the purchase of new cars (although hybrid and electric) in an effort to support the automotive industry, and many cities in the US, such as Denver and Boston, adopt measures that favor the use of cars by loosening or suspending parking enforcement penalties.

The future of urban transportation post-COVID-19 is still unclear, as previous approaches to mobility face constraints of existing infrastructure and service provision [42]. The existing literature highlights the need for greater flexibility in setting "smart mobility restrictions, based on the transmission risk of different transportation modes" [3], greater flexibility in the transportation modes (such as experimentation with connected micromobility options), emphasis on individual responsibility $[43,44]$, recovery of public transport [34], and the exploitation of new technologies (e.g., using data analytics, artificial intelligence, and IoT) in order to improve the efficiency of the transport system $[45,46]$.

The challenge for sustainable mobility, however, does not merely depend on transport policy itself, but also requires collaboration across different policy areas and the users. In the spatial planning domain, recommendations focus on complete street policies designed to accommodate diverse modes, users, and activities [47], and multi-modal access to transportation. Complete streets had already become popular before the pandemic, with many cities reducing drive-alone streets, expanding their cycling networks, and creating more pedestrian-friendly streets in both neighborhoods and downtown areas [48]. The overall success, however, will depend on the level of horizontal and vertical integration $[49,50]$.

\subsection{Smart City Technologies: An Unexplored Pool of Potential Solutions}

The pandemic showed, like no crisis before, the power of technology. This became evident with the first lockdown with the immediate prevalence of teleworking, aimed to secure social distancing while mitigating the economic impact of the crisis, but also with the acceleration of the digitalization of services including remote education, e-health, and e-administration [51].

Technology offered plenty of opportunities to pave the way for the emergence of bottom-up initiatives targeting community self-help and mutual support through social media and online platforms. These initiatives bring communities together, encourage networking, develop innovative solutions and collaborative infrastructure in support 
of those in need, and, therefore, shape social resilience by mobilizing collective intelligence $[25,52,53]$.

At a more technical level, the use of data, the exploitation of analytics, and smart city technologies have proven very useful to understanding the magnitude of the current crisis and to designing effective mitigation strategies [46,54]. The pandemic acted as an accelerator in the experimentation of many emerging technologies, from drones and delivery robots to scanning human encounters through cell phone location data [55,56]. Several institutions have been collecting data of the new outbreaks and statistics, while scientists correlate COVID-19 cases and environmental variables (e.g., air pollution), urban formations (e.g., population density), and other societal data (such as income, poverty rates, and demographics) of the affected areas $[57,58]$. Yet the level of adoption by city authorities and policymakers is still unclear.

Over the last decade, smart city technologies have increasingly been adopted in all aspects of urban mobility, from monitoring and optimizing the performance of existing infrastructure to solutions focusing on user experience and satisfaction. The embodiment of artificial intelligence in urban spaces, urban transport infrastructure, and autonomous cars aims to overcome the challenges of increasing travel demand, $\mathrm{CO}_{2}$ emissions, safety concerns, and environmental degradation [59-62]. The use of sensors and IoT for real-time data mining and pattern detection in high-frequency data facilitates the development of more intelligent mobility solutions and can play a crucial role in urban policy overall, as it allows a better understanding of the city through the analysis of fast dynamics [63].

Smart city advancements could be further utilized in the context of the pandemic to address new needs that emerged in the urban mobility sector. The economic, social, and environmental benefits of public transport cannot be ignored, and therefore, its future should be re-examined in terms of the provided services and customer experience [33]. New rules of operation (e.g., IoT and smart systems for monitoring and controlling occupancy), securing complete functionality, improvements to infrastructure (e.g., smart ventilation systems, thermal cameras for monitoring passengers' temperature), and the use of automated systems and services (informing about occupancy level and alternatives and influencing real-time demand, online ticket purchase, etc.) are among the proposed options [6]. These solutions should be integrated with other transformations in the mobility sector, such as the use and integration into the transport system of more flexible modes of transportation, such as micromobility services (e.g., apps for scooter and bike-sharing systems) as well as with planning interventions (wider bike lanes).

The future of urban sustainability depends on the recovery of mass transit ridership, and the complementary use of other sustainable means in order to avoid auto-dependence, congestion, and an increase in pollution [33]. However, this challenge can only be addressed in combination with changes in city planning, and the success of this effort will reflect cities' readiness to deal with major challenges [19]. The digital transformation of the urban transport ecosystem using smart city technologies can lead to the development of network effects at the physical and digital space, but also to digital externalities that altogether strengthen the sustainability and resilience of this urban domain [64].

\section{Research Design and Methodology}

The pandemic imposed a state of emergency for city planners and urban operators in order to address the rapidly changing conditions. Although many of the policy responses and emerging practices were of a temporary nature, it is important to further examine them since they show a trend in the course of action. Our aim is to discuss whether these policies are targeted towards smart growth and sustainable mobility, as well as whether they incorporate smart city technologies that create opportunities for efficiency, optimization, and intelligence.

The collection and classification of policy interventions is a common and useful analytical tool to facilitate discussion about some predefined elements and compare policies across different places $[65,66]$. We collect 60 different initial policy responses (adopted 
during the first 8 months of 2020) related to urban mobility from 86 cities around the world (Table A1). The difference between the number of cities and policy responses examined is due to some common responses (e.g., pedestrianization) that are met in most cities. We included in our analysis cities of different sizes and levels of complexity.

Our aim was not to exhaustively examine all measures taken by the cities examined, but rather to create an extensive catalogue of different initiatives and policy measures adopted during the first months of the COVID-19 crisis and that directly affected urban mobility. They reflect the responsiveness and flexibility of the urban and transport ecosystem in each area against the health crisis. We should clarify that we did not check the duration of the imposed measures, nor their level of efficiency in restricting the pandemic. The measures adopted were dependent on the specific epidemiologic situation of each city, which may vary in terms of impact or the point at which they may be in their epidemiologic curve, as well as on the restrictions imposed by the national government. Additionally, the measures reflect the existing transportation modes in each area, the level of development, etc. We focused on measures and initiatives that were designed and implemented either by the municipality itself or by the local service (mobility) provider. The time frame of our analysis covers a period where COVID-19 had spread throughout the world, in all countries and regions, even, as mentioned above, with a different level of impact.

To collect policy responses from different cities, we accessed the platforms and repositories of international organizations, which were subsequently reconfirmed through other official resources. We specifically used the following repositories:

- COVID Mobility Works (https://www.covidmobilityworks.org/, accessed on 30 November 2020), an independent platform dedicated to collecting, synthesizing, and sharing mobility initiatives that are keeping the world moving during the COVID-19 pandemic.

- Cities for Global Health (https://www.citiesforglobalhealth.org/, accessed on 30 November 2020), a repository launched by Metropolis and the Euro-Latin-American Alliance of Cooperation among Cities (AL-LAs), with initiatives, projects, and actions started by cities that show how local and regional governments are managing the crisis and planning their recovery.

- The OECD library of city policy responses to COVID-19 [20]. Additionally, the International Transport Forum (ITF) of OECD has published 3 relevant transport briefs: "Re-spacing our Cities for Resilience," "Electric mobility: Taking the Pulse in Times of Coronavirus", and "How Transport Supports the Health System in Corona Times". All reports compile case studies from around the world.

- The National Association of City Transportation Officials (NACTO) library's "Streets for Pandemic Response and Recovery" [67] (https:/ /nacto.org/program/covid19/, accessed on 15 September 2020), documenting pandemic rapid-response strategies and emerging practices from cities and transit agencies around the world.

Apart from these, we also used some additional information from the following three sources:

- The EIT Urban Mobility COVID-19 repository [7] (https: / / www.eiturbanmobility.eu/ covid-19-what-is-happening-in-the-area-of-urban-mobility /, accessed on 15 September 2020), an initiative by the European Institute of Innovation and Technology (EIT) that publishes news and articles in regard to what is happening in the area of mobility during the pandemic.

- The Polis Network EU (https://www.polisnetwork.eu/document/resources-covid19-mobility/, accessed on 15 September 2020), a network of European cities and regions working together to develop innovative technologies and policies for local transport that created a section showcasing both cities' and regions' mobility-related responses during confinement measures and plans for after confinement measures have been lifted. 
- The Pedestrian \& Bicycle Information Center (Pedbikeinfo), which has collected 879 initiatives that promote cycling through different means in the context of the pandemic and beyond.

To analyze the measures taken at an urban level as a response to the challenges posed by the pandemic (RQ1), we used a set of criteria. Firstly, we focused on the type of the policy instrument, the challenge it wants to address, as well as its time horizon. We classified all policy responses into the following types of instruments:

- Legislative and regulatory, including guidelines, rules, limits, and binding requirements, which in cases of noncompliance will be followed by sanctions, as well as any authorization, license, or permit under transport-related legislation;

- Planning, including land use, urban planning, and zoning;

- Public or private investments, particularly investments in infrastructure;

- Economic and financial, such as revenue-generating instruments, subsidies, licenses, user benefits, cost reductions, and redistributions;

- Educational/information based, including education and training, information campaigns, capacity building, monitoring, and access to information;

- Organizational and cooperation-based instruments such as voluntary commitments, negotiations, networks, improvements/changes in the transport services offerings, adapting to emerging needs, etc.

With respect to the challenges they aimed to address, the policy measures were grouped as follows (potentially in more than one group):

- Relieve the pressure on the health system and facilitate medical professionals, essential workers, and COVID-19 patients;

- Provide alternative means of transport;

- $\quad$ Promote green and active mobility;

- Management of public space;

- Secure health standards in the transport system, reduce the risk of contamination.

In terms of time horizon, we divided the measures into (i) permanent and (ii) temporary, although both cases depended significantly on the epidemiological condition of a place at any given time, the citizens' acceptance level, and the decisions of the policymakers.

Second, since many of the policy measures identified constituted planning interventions, we aimed to identify their relevance and contribution to the smart growth paradigm (RQ2). The principles of smart growth seem to have been reformulated over time, seeking to respond to the realities of planning. We assessed whether the policy measure examined was linked to each one of the abovementioned principles (yes/no) and, if yes, its contribution (positive/negative).

Third, we associated each of the measures with the principles of sustainable mobility (RQ2). As a method of assessment, we used the list of sustainable mobility indicators developed by the World Business Council for Sustainable Mobility [68]. These indicators are well aligned to the objectives of European Union's Sustainable Urban Mobility Plans (SUMP), which promote access to key destinations and services, transport safety and security, reduction of pollution and energy consumption caused by transport, improvements in efficiency and cost reduction, as well as improvements in the attractiveness of the urban environment [69]. The sustainable mobility indicators were associated with the policy measures with a yes/no if they were relevant and contributed to a positive change of the respective indicator. It was possible for a policy response to have an impact (positive or negative) on more than one indicator.

Finally, advancing on the specific characteristics of each measure, we focused our attention on the innovation mechanism activated and the level of ICT penetration (RQ3). To do this, we initially explored whether there was an ICT component (yes/no) and if there was, we evaluated it using the three scales of digital transformation as proposed by [70], which are: 
- Digitization: activities performed in digital space but routines that govern these activities (and their underlying rules) remain unchanged, as performed in the physical or social space of cities;

- Optimization: activities performed in digital space, but routines that govern these activities are optimized to the best configuration by automation and AI;

- Innovation: activities performed in digital space, but routines that govern these activities are replaced by more fit ones, defined within a cyber-physical system of innovation.

The results of the analysis are described in Section 4.

\section{Analysis of the Urban Responses to the Pandemic}

Our analysis is based on a collection of 60 policy responses/actions that were retrieved from 86 cities of different size and characteristics across the globe (Table 1). These are initial responses to the pandemic, since our analysis was conducted during the first eight months of 2020; therefore, they reflect aspects of responsiveness, flexibility, and adaptability of the respective urban ecosystems. The geographic location of the cities of our analysis is shown in Figure 1.

Table 1. Sustainable mobility indicators [68].

\begin{tabular}{cc}
\hline Sustainable Mobility Indicators & \\
\hline Emissions of greenhouse gases & Comfort and pleasure \\
Energy efficiency & Accessibility for mobility-impaired groups \\
Net public finance & Affordability of public transport for poorest \\
Congestion and delays & group \\
Economic opportunity & Security \\
Commuting travel time & Functional diversity \\
Mobility space usage & Intermodal connectivity \\
Quality of public area & Intermodal integration \\
Access to mobility services & Traffic safety \\
Noise hindrance & Resilience for disaster and ecologic/social \\
Air polluting emissions & Occupancy rate \\
\hline
\end{tabular}

With regards to the type of policy (Figure 2), most policy responses were organizational and co-operation based and referred to changes, improvements, and offers of new services, such as the transfer of patients to and from hospitals using buses (Gurugram) or the development of demand-responsive micromobility services to help health workers (Abu Dhabi) and/or customers who were experiencing lost fixed-route service (Columbus). Such responses reflect active engagement and a bottom-up organization of mobility providers and stakeholders and create a fertile ground for the emergence of innovative, flexiblerouting micro-transit services that require the use of the instant exchange of information, enabling an extra real-time matching of demand and supply on top of in-advance booking, thus extending its accessibility to a wider group of people.

Next were the financial and planning responses, which have been widely adopted by many cities. The economic and financial responses mainly referred to free access or reduced fees in the use of mobility services and related infrastructure, of micromobility, or of other means of mobility (taxis, public transit, toll fees), and they were primarily targeted to medical professionals and essential workers. Financial responses could also include financial incentives for bike purchase (Nottingham) or bike donations (Amsterdam), both of which could positively affect mobility behavior in the long term. On the other hand, we found subsidies given to taxi drivers to keep them operating (Chicago). 


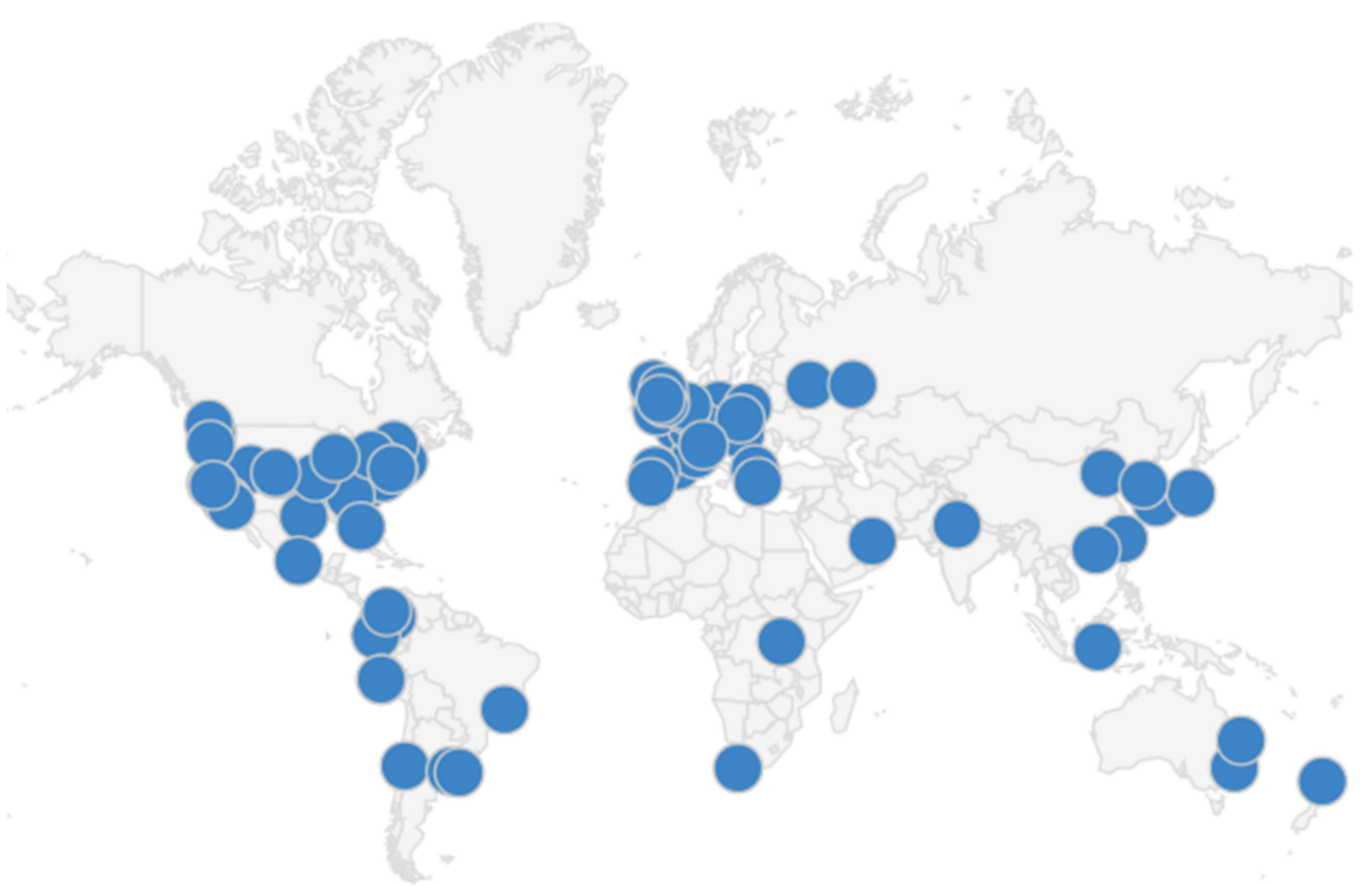

Figure 1. Geographic location of the cities whose policy measures were analyzed. Source: own elaboration.

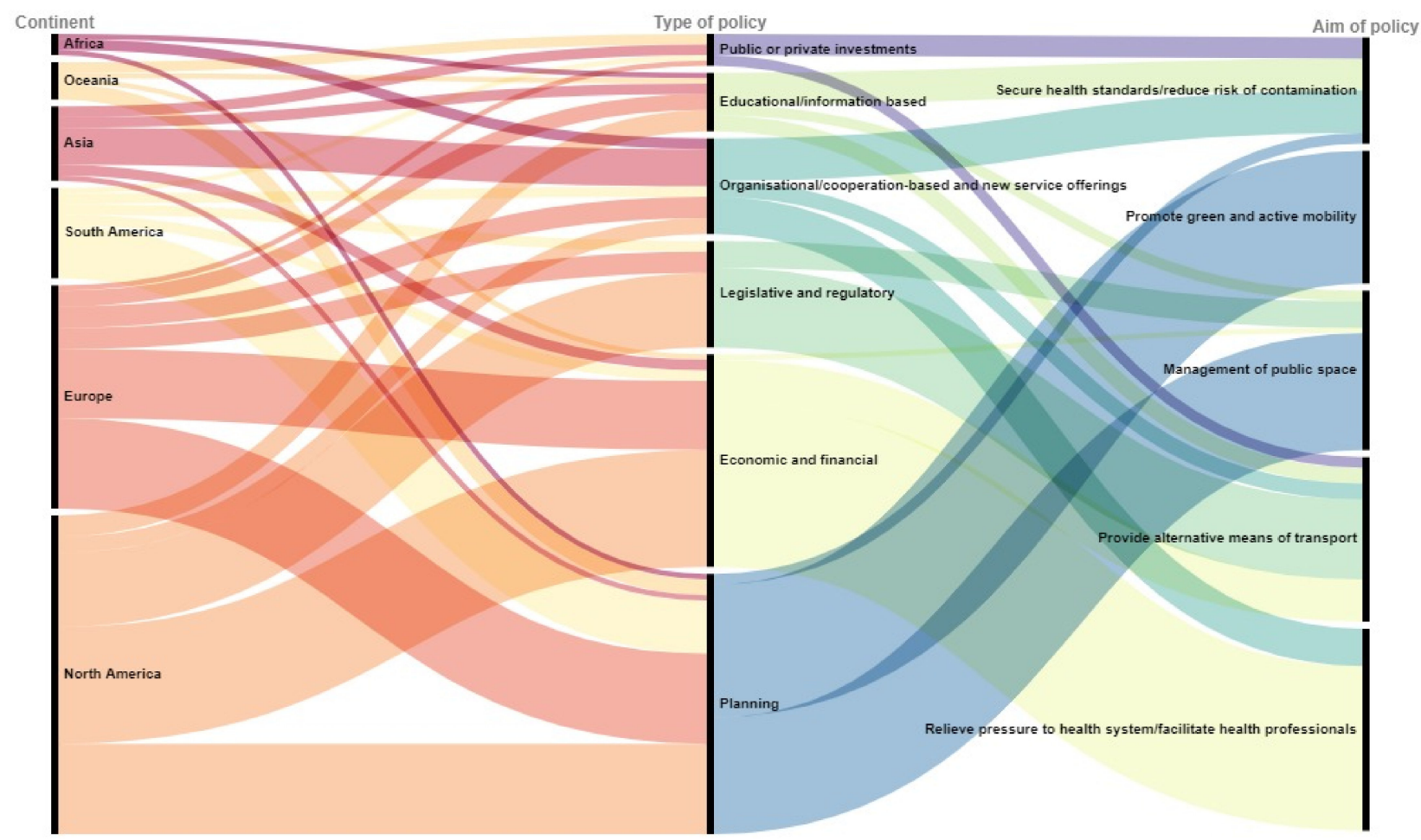

Figure 2. Location, type, and aim of city policy responses in relation to urban mobility during the first eight months of 2020. Source: own elaboration.

The spatial planning responses included changes in the land use, considering patterns of flows and the relationship between the spatial structure of cities and emergent mobility patterns/behavior. Among the most popular measures were the pedestrianization of streets, the creation of jogging lanes, the development of pop-up (temporary) cycleways, and the extension of sidewalks and of the bike lane network. 
Fourth were the information and educational measures aimed at teaching a skill and at the collection and utilization of useful information targeting both citizens, with the aim to influence behavior, and mobility stakeholders, aiming to improve capacity building and optimize or increase their mobility services. Examples here included dashboards and open data portals collecting, organizing, and providing mobility and health-related information (Vancouver, Fukuoka), public awareness campaigns to educate transit riders and workers on new safety and preventative measures to reduce community transmission, and even free bike lessons to promote safer alternatives for transport (Newcastle). A more detailed analysis of such measures as well as their direction with regards to the smart growth paradigm is given later in the text.

Fifth were the legislative and regulatory measures (mostly temporary), such as the declaration of bicycle shops as essential businesses during the lockdown (Columbus, San Francisco) and the suspension of parking enforcement policy, a measure widely adopted in North American cities (Los Angeles, New York, Denver, and Mississauga, among others). In this category we found measures of a somewhat spatial planning character, such as the closure of open spaces such as parks, waterfronts, and other leisure-related areas to avoid crowding (Milan, Thessaloniki). These responses were not included in the "planning" group, since they did not reflect a change in land use, but rather a temporary restriction of access to these sites.

Finally, a small share of responses referred to public and private investments and the upgrading of physical infrastructure, such as the installation of surveillance cameras on trains (Beijing), automated mechanisms on pedestrian crossings that do not require physical touch (Brisbane), and a significant increase in bike and scooter fleets to meet the increasing demand (Rotterdam).

The measures described above aimed to address the challenges of the pandemic in relation to the emerging needs of the mobility sector. Although most of the city responses analyzed had more than a single challenge to address, the majority of them focused on improving the monitoring systems, mechanisms, and health safety standards of urban transportation in order to reduce the risk of contamination (Figure 2). Furthermore, a large share of responses focused on promoting green and active mobility and the management of open and public space, since the success of the first requires a redesign of the public space not only in terms of infrastructure development but also in terms of land use and regulations that manage contradictory uses. It has to be mentioned, however, that although the management of open spaces can be considered supplementary to the ones promoting green mobility, there were cases where they acted in a reverse mode (e.g., restricting the access of pedestrians to open spaces). Finally, we found policy responses aimed at the promotion of alternative modes of transport as well as services targeted to health professionals and essential workers by offering a wide range of free or low-cost mobility options.

In terms of their time horizon, most of the policy responses examined were of a temporary nature, highlighting the evolutionary nature in which new planning paradigms often evolve and new rules are adopted, especially when they cause significant alterations in existing trajectories of policies and outcomes [71]. Among the temporary planning and regulatory responses were the expansion of transit areas to ensure social distancing and the ban of access to parks and open spaces. In many cases, the measures were fragmented and exposed implementation deficiencies, whereas in others, they were an opportunity to implement bold strategies that would completely transform urban living beyond the pandemic.

This was the case in Milan, where a transportation strategy carefully designed before the pandemic was implemented earlier due to the pandemic [72]. On the other hand, in the case of Athens, the mayor's plan to create the "Great Walk" by blocking the access of cars on central avenues without extensive prior preparation was harshly criticized and cancelled. Nevertheless, it revealed the need for further debate on the urban transformation of the city [73]. 
Focusing on smart growth, we revealed that even short-term and immediate responses of cities to the challenges of the pandemic created an underlying advancement towards this planning paradigm, although only four out of 10 smart growth principles seemed to be relevant (given that they only placed emphasis on mobility). These were (i) to create walkable neighborhoods through actions of pedestrianization and the extension of sidewalks; (ii) to preserve open space with street improvements and pop-up plazas; (iii) to provide a variety of transport choices by providing supplementary transit services, expanding the bike lane network, and integrating the overall mobility network; and (iv) to encourage community and stakeholder collaboration in development decisions through the organization of hackathons, the provision of data portals, and the collaboration of different mobility stakeholders to develop new mobility services.

Using the smart growth components that were directly linked to urban transport and mobility (Figure 3), we found that more than $70 \%$ of the policy measures collected were positively relevant to smart growth, aiming firstly at the promotion of public transit through activities that monitor safety regulations (use of masks, distancing, passenger limits) and turn public transport into safer choices for their users. Other measures focused on the development of facilities for cycling and other forms of sustainable micromobility, and promoted pedestrianization and systems integration by providing collective information of different transport means to allow citizens adapt their behavior based on the existing situation and by surveying the community ridership demands to support related planning efforts. More than a quarter of the total policy measures were not relevant or had a contradictory nature to smart growth, such as the suspension of parking enforcement policy, which encouraged the use of cars; the closure of open spaces; and even the extension of sidewalks for the benefit of restaurants and businesses.

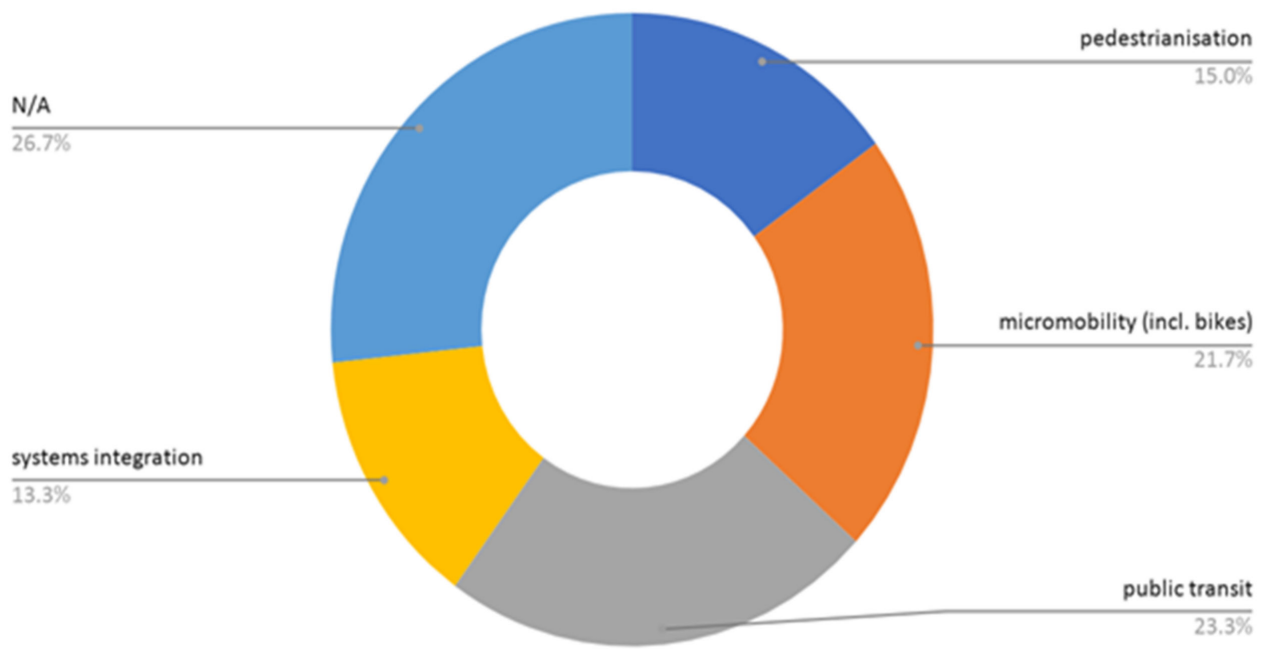

Figure 3. Smart growth objectives. Source: own elaboration.

Comparing the total policy responses with the ones of a spatial planning nature, we revealed a different set of priorities. Spatial planning as a mitigation strategy against the pandemic related more to the promotion of individual active mobility, such as walking and cycling. More specifically, eight out of the 13 responses promoted pedestrianization; three aimed at facilities for cycling, including other forms of micro-mobility; one measure focused on public transit promotion; and one was not considered relevant (wider sidewalks for restaurants and businesses), since it did not promote any of the smart growth principles. In fact, the existence of many measures promoting cycling was confirmed by the European Cyclist Federation, which tracked the commitment of local and other public authorities to create new bike lanes in Europe, with the total length exceeding $2000 \mathrm{~km}$ in October 2020.

Overall, the combination of spatial planning- and mobility-related measures created a complete pool of actions that a city could use to articulate an integrated reaction to the 
pandemic. For example, reducing the speed limits and the access of cars to specific blocks of different neighborhoods, the widening of pavements and cycling lanes, and creating a multi-modal transportation system with better connections to transit stations, provide a healthy alternative to urban mass transportation. Such is the "15-minute city" strategy for Paris, a planning concept that requires minimal travel for residents to meet their daily needs. Interestingly, after the lifting of the first lockdown in June, the traffic in French bike lanes rose by $29 \%$ on average, with differences being observed between urban (increased by $33 \%)$, peri-urban $(+17 \%)$, and rural zones $(+16 \%)$, and the number of cyclists passing in the bike lanes monitored by $182 \mathrm{~m}$ rose by $67 \%$ between June and August, in comparison to the same period in 2019 [37].

An emphasis on interconnected cycling and pedestrian networks, combined with an approach for adaptive emergency reuse of infrastructure and means of transportation, was identified as one of the most successful strategies to bring resilience in urban centers during the pandemic. The measures taken revealed the need for new and innovative business models in urban mobility that are more flexible and personalized. These alternatives are linked to micromobility and typically promote the use of shared bikes, e-bikes, scooters, e-scooters, and other vehicle types that are shrinking the physical footprint needed to move people over relatively short distances.

Focusing on sustainable development (Figure 4), we revealed that most policy responses aimed to improve comfort and pleasure, defined by [68] as "the physical and mental comfort of urban transport and services for all people." Since many policy responses referred to the promotion of active mobility, the respective indicator was positively affected. Furthermore, we saw improvement in important environmental indicators, such as the reduction of greenhouse gases emissions, energy efficiency, and mobility space usage. The positive effects should be counterbalanced with the negative ones, the most significant of which was the increase in commuting travel time and in space usage, i.e., the proportion of land use taken by all city transport modes, and the quality of public areas, an indicator that related to the presence in the city of streets and squares that offer sociability and a good image. Of course, the latter contradicts social distancing, and its negative trend can therefore be justified.

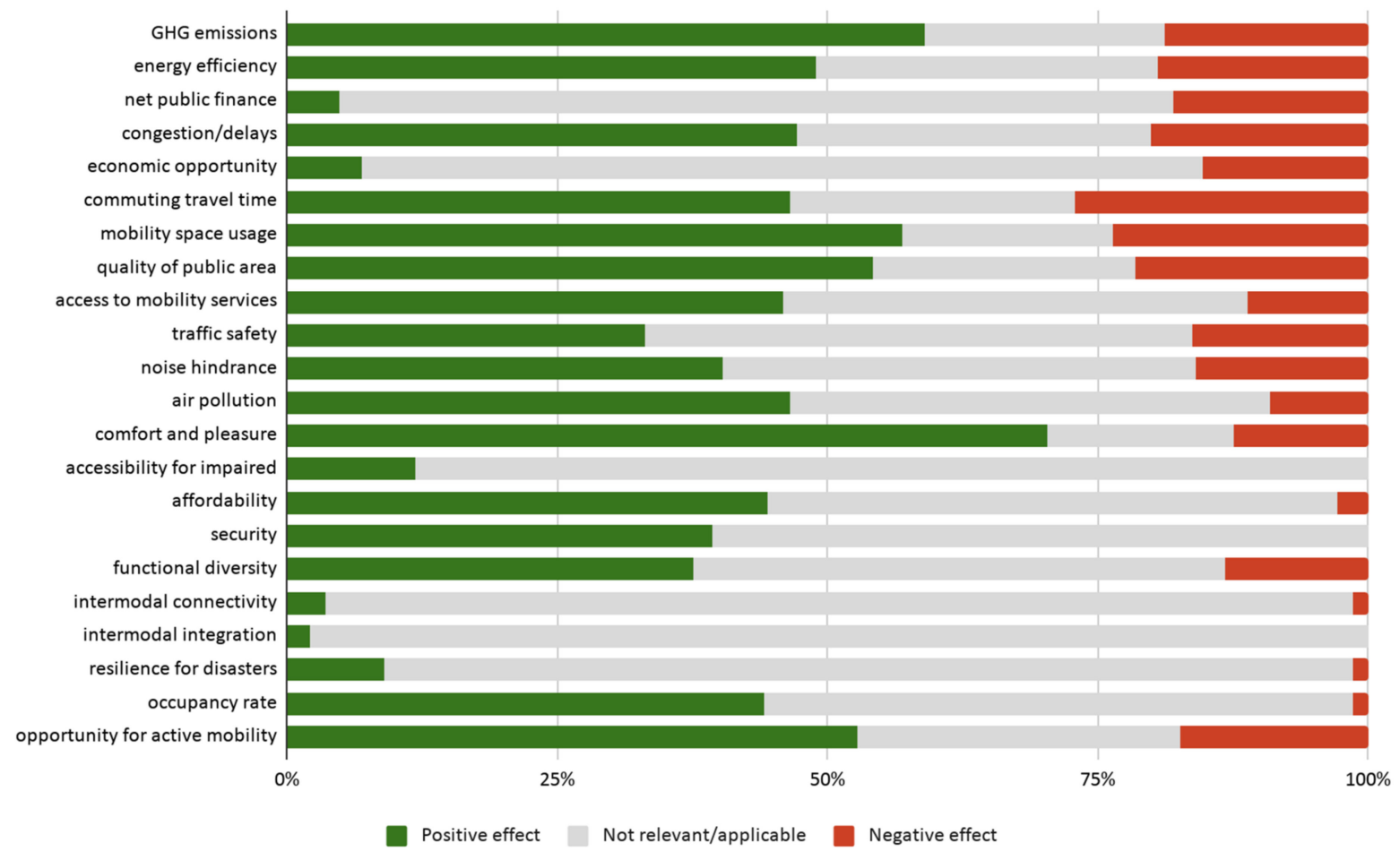

Figure 4. Contribution of policy measures to sustainable mobility. Source: own elaboration. 
With regards to ICT penetration, it is impressive that most policy responses did not incorporate ICT, and those that did remained at a low level of digital transformation (Figure 5). More specifically, the vast majority of the policy responses examined did not incorporate ICT at all, and only $12.4 \%$ of them included an ICT component. Although it is difficult to accurately assess the exact level of digital transformation without an in-depth study of the policy measures and the changes made in behavior, routines, and processes after their implementation, we observed that most measures that were ICT based (or at least included some level of automation) constituted activities performed digitally while the routines that govern these activities remained unchanged. This was the case of Hong Kong (pilot action), where the cleaning and disinfection of train compartments and stations is being performed by robots instead of people, or Beijing, where cameras are used to check compliance with mask wearing. The optimization of routines was observed only in $10 \%$ of the policy measures, such as the apps showing bus occupancy (Barcelona) or the in-app metro reservation system (Beijing), which can shift the mobility routines of citizens towards more safe hours/schedules, or the efficiency created by the use of automated pedestrian crossings (Brisbane) in reducing the potential contamination of pedestrians. Only one policy response was considered to reach the level of innovation, since it combined efficiency from different ICT-based solutions that change the governing routines of these operations into ones that are more fitted to the problem. This was the case of Seoul's effort to use advanced tracing techniques such as geolocalization data, bank-card usage, and video surveillance for contact tracing and to ensure social distancing. It should be mentioned, however, that the level of service transformation through the use of ICT is difficult to assess without an in-depth analysis of the changes in the service itself.

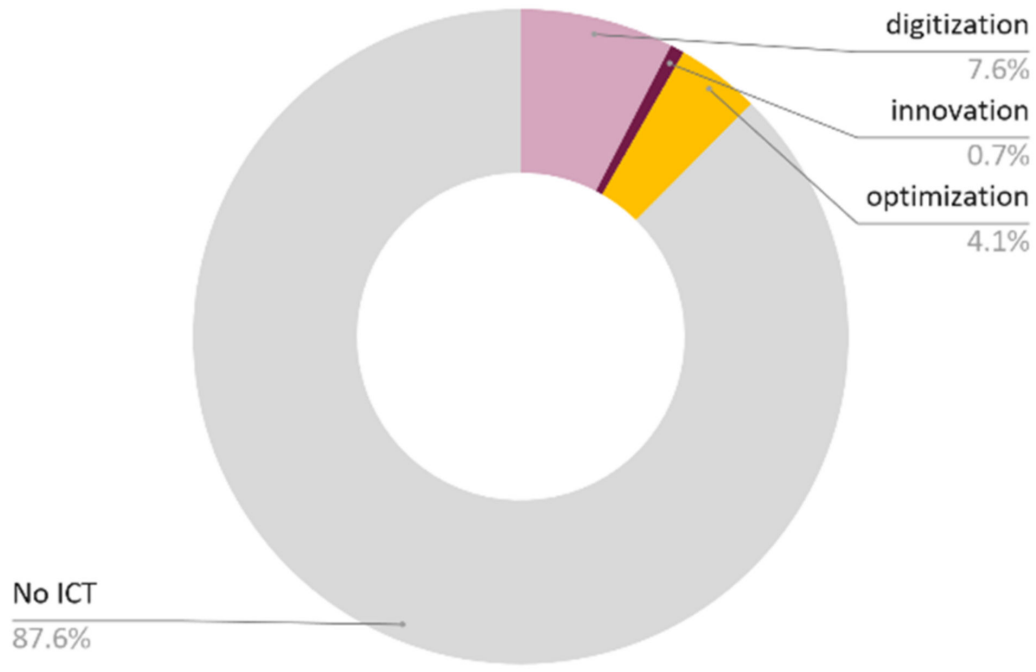

Figure 5. Level of ICT penetration. Source: own elaboration.

\section{Conclusions}

We analyzed 60 different mobility-related policy responses to the COVID-19 crisis in cities from all over the world. Our findings suggest that most policy responses are organizational, involving new ways of operation and new services provision, thus increasing the flexibility of the transport ecosystem in each city as well as its resilience against the challenges of this crisis. Other popular types of policies are economic/financial and planning interventions, mostly in the sense of temporary, reversible adaptations of the urban space. The main aim of the policies is to reduce the risk of contamination in the use of existing transport infrastructure as well as to promote green and active mobility as a safe alternative. Although initial and, perhaps, short-term changes, they seem to be in line with smart growth and sustainable development objectives (with some notable exceptions), yet they demonstrate limited levels of ICT incorporation/digital transformation. This seems contradictory to the belief that the pandemic has accelerated smart city development. 
The disruption caused by the pandemic must become an opportunity for change towards sustainability, since the transport sector in many cities causes negative environmental and health costs. Sustainable transport has emerged as a key policy priority and requires changes that exceed this specific domain, spanning from urban planning, education, the use of digital technologies, and so on. Even before the current pandemic, urban centers needed to significantly change their spatial planning approaches to meet the global goals outlined in the Paris Agreement, the Sustainable Development Goals, and the New Urban Agenda with regards to social, environmental, and economic sustainability. The pandemic crisis and the enforced lockdowns caused great confusion, revealed inefficiencies, and highlighted new challenges, but they also created opportunities to run pilots (e.g., infrastructure for active mobility, equal distribution of green spaces, adoption of innovations in the transport sector) and re-evaluate spatial planning policies and urban strategies for resilience and sustainability. Our findings suggest that the COVID-19 crisis revealed significant opportunities for urban planning and mobility in cities. The actual long-lasting impact on mobility will depend on the preservation of healthy and sustainable alternative urban design and sustainable mobility strategies, and on the responsiveness of city authorities in the use of new technologies that allow them to create services and cooperation models that respond to the emerging reality and needs.

From the sum of smart growth principles, urban responses to the pandemic mainly focus on a variety of transportation choices and the promotion of walking. We saw that the change in the lifestyle and behavior of citizens resulting from the lockdown was perceived by many cities as an opportunity to promote sustainable development patterns through open spaces, parks, and alternative models of urban transportation. The transition to inclusive, green, and smart mobility is not a given, as measures continue to be temporary and experimental.

The need to envision the new normal in fair and sustainable terms and on a longterm basis, enabled by ICT, remains. With regards to ICT adoption, it is impressive that most policy responses do not incorporate ICT and those that do, remain at a low level of digital transformation, focusing mainly on the use of open data and IoT infrastructure to inform about availability, performance, and health dangers. Although smart, digital, and intelligent cities have been an objective for policymakers across the world for several years, emergency responses fail to follow a similar path. There are a lot of unexploited technologies for the transformation of mobility services that could address the challenge of each city without compromising sustainability. We also saw examples of local or national governments that positioned themselves against the massive tracking of citizens and collection of private data. All the above create expectations for a new approach, a rethinking of the concept of smart cities and their contribution to sustainability in urban mobility and development.

A question that remains unanswered is how means of public transportation can effectively adapt to the current situation. Cycling and walking solve local problems during confinements. However, when restrictions are lifted, people have to cover longer distances, re-integrate into public life, and therefore use public transportation, which has to be safe and reliable. It is pivotal to not waste the efforts made in the last few years towards sustainability and the promotion of public transport and collective mobility. As the situation evolves and the challenges of urban living in the pandemic remain, there are many transformations that need to happen.

Author Contributions: Conceptualization, C.K.; methodology, C.K., E.O., I.P.; investigation, C.K., E.O., I.P.; writing—original draft preparation, C.K., E.O., I.P.; writing—review and editing, C.K.; visualization, C.K., E.O., I.P.; project administration, C.K.; funding acquisition, C.K. All authors have read and agreed to the published version of the manuscript.

Funding: This research received funding from the European Union's Horizon 2020 Marie SkłodowskaCurie (MSCA-RISE-2018) project TREND—“Transition with Resilience for Evolutionary Development". Grant agreement 823952. 
Institutional Review Board Statement: Not applicable.

Informed Consent Statement: Not applicable.

Data Availability Statement: Not applicable.

Conflicts of Interest: The authors declare no conflict of interest.

\section{Appendix A}

Table A1. Annex: Mobility-related responses from cities around the world.

\begin{tabular}{|c|c|c|}
\hline & City & Measure Description \\
\hline 1 & Seoul & $\begin{array}{l}\text { Use of advanced tracing techniques such as geolocalization data, bank-card usage, and } \\
\text { video surveillance for contact tracing and to ensure social distancing. }\end{array}$ \\
\hline 2 & Beijing & $\begin{array}{c}\text { Trains outfitted with smart surveillance cameras that can detect passengers who are not } \\
\text { wearing masks. }\end{array}$ \\
\hline 3 & Kinshasa & $\begin{array}{l}\text { An SMS system developed in a hackathon makes it possible to trace the chain of } \\
\text { contamination by identifying people who have used the same public transport vehicle } \\
\text { with a virus carrier. }\end{array}$ \\
\hline 4 & Bogotá & $\begin{array}{l}\text { A hackathon was organized for the exploitation of data to monitor the impact and } \\
\text { reduce the probability of transmission in public transportation. }\end{array}$ \\
\hline 5 & Kigali, Nice & Drones with megaphones ask people to stay home. \\
\hline 6 & Cape Town & $\begin{array}{l}\text { The Department of Health has surveillance systems for screening and monitoring cases } \\
\text { with a travel history and close contacts within the affected areas. }\end{array}$ \\
\hline 7 & Mexico City & $\begin{array}{l}\text { City partners with Google Maps and Waze to monitor mobility trends and for } \\
\text { telesurveillance of concentrations of people. }\end{array}$ \\
\hline 8 & Portland & $\begin{array}{l}\text { Micromobility companies offer data to study transport behavior and design } \\
\text { COVID-19 responses. }\end{array}$ \\
\hline 9 & Barcelona & An app shows bus occupancy levels. \\
\hline 10 & Fukuoka & $\begin{array}{c}\text { The municipality provides congestion information during weekday morning } \\
\text { rush hours. }\end{array}$ \\
\hline 11 & Tokyo & $\begin{array}{l}\text { Digital contact tracing service notifies users if someone who used the same facilities } \\
\text { tests positive for COVID-19. }\end{array}$ \\
\hline 12 & Katowice & An open-source database with on demand travel services. \\
\hline 13 & Tokyo & $\begin{array}{c}\text { One-stop database on the real-time COVID-19 situation, including the number of } \\
\text { infected people, their status, features, number of inquiries to the call center, and number } \\
\text { of people using the subway. }\end{array}$ \\
\hline 14 & Sydney, Newcastle & Free cycling lessons. \\
\hline 15 & Vancouver & $\begin{array}{l}\text { Online dashboard to inform people of the city's emergency response to the spread of } \\
\text { COVID-19 and how vehicle, bicycle, and pedestrian traffic has evolved. }\end{array}$ \\
\hline 16 & Austin & Signal adjustments to optimize timing for essential trips. \\
\hline 17 & Chicago & $\begin{array}{l}\text { Public awareness campaign to educate transit riders and workers on new safety and } \\
\text { preventative measures to reduce community transmission. }\end{array}$ \\
\hline 18 & $\begin{array}{l}\text { Santa Monica, } \\
\text { Stuttgart }\end{array}$ & Unlimited rides with shared bicycles. \\
\hline
\end{tabular}

Bogotá, Vancouver,

Denver, Los Angeles,

Washington, D.C., San Diego,

19 Kansas City, New York, Boston, Chattanooga,

Free access (limited or unlimited time or membership) to an e-bicycle fleet for medical workers/volunteers and couriers.

California and Santa Monica,

Cardiff, Glasgow, London,

Moscow 
Table A1. Cont.

\begin{tabular}{|c|c|c|}
\hline & City & Measure Description \\
\hline 20 & $\begin{array}{l}\text { Baltimore, Denver, Detroit, Los } \\
\text { Angeles, } \\
\text { Portland, San Francisco, Tampa, } \\
\text { Washington, D.C }\end{array}$ & $\begin{array}{l}\text { Free access (limited or unlimited time or membership) to a scooter for medical workers } \\
\text { or volunteers. }\end{array}$ \\
\hline 21 & Budapest & Reduction in the fees in the bicycle-sharing system. \\
\hline 22 & Nottingham & Financial incentives for bike purchase and bike donations. \\
\hline 23 & Amsterdam & Offer of free bikes to students. \\
\hline 24 & Birmingham & Free bicycle stands are offered to companies, hospitals, schools, and other organizations. \\
\hline 25 & $\begin{array}{l}\text { Medellín, } \\
\text { Rotterdam }\end{array}$ & $\begin{array}{l}\text { Increased fleet of shared micromobility (bikes and scooters) to prevent crowding in } \\
\text { public means of transport. }\end{array}$ \\
\hline 26 & Sydney, Brisbane & Automated and smart pedestrian crossing. \\
\hline 27 & $\begin{array}{l}\text { Abu Dhabi, Paris, } \\
\text { Nancy (not free) }\end{array}$ & A free on-demand microtransit shuttle service for healthcare workers. \\
\hline 28 & Columbus & On-demand micromobility service using surplus vehicles. \\
\hline 29 & Columbus & $\begin{array}{l}\text { On-demand transit pilot in specific areas to help customers who are experiencing lost } \\
\text { fixed-route service. }\end{array}$ \\
\hline 30 & $\begin{array}{c}\text { Auckland, Santiago, Buenos } \\
\text { Aires, Brooklyn, Athens, } \\
\text { Victoria, Montreal, London, } \\
\text { Paris }\end{array}$ & $\begin{array}{l}\text { Extended sidewalks to create more space for physical distancing using asphalt ramps, } \\
\text { white safety posts, and paint. }\end{array}$ \\
\hline 31 & Sydney & Allocation of funds for pop-up street improvement. \\
\hline 32 & Jinja & Redesign of central market and traffic flow to maintain social distancing. \\
\hline 33 & $\begin{array}{l}\text { Montevideo, Palo Alto, Salt } \\
\text { Lake City, } \\
\text { Brussels }\end{array}$ & Pedestrianization of streets. \\
\hline 34 & Amsterdam, Cardiff & Transforming a shopping street into a one-way street for pedestrians and bikes. \\
\hline 35 & Birmingham & Creation of jogging lanes. \\
\hline
\end{tabular}

Sydney, Auckland, Cali, Mexico

City, Bogotá, Quito, San Borja,

36 Lima, Montreal, Paris, Brussels,

Pop-up (temporary) cycleways and acceleration of the extension of the cycling network.

Turin, Leeds, Leicester

\begin{tabular}{|c|c|c|}
\hline 37 & Berlin & Expansion of cycling lanes. \\
\hline 38 & Buenos Aires & $\begin{array}{c}\text { Provision or expansion of transit-only/transit-priority lanes to ensure } \\
\text { surface-level transit. }\end{array}$ \\
\hline 39 & Banjarmasin & Adapting school zone drop-off and pick-up areas to ensure social distancing. \\
\hline 40 & Montreal, Vancouver & Increase in the number of green spaces/pop-up plazas. \\
\hline 41 & $\begin{array}{c}\text { Thessaloniki, New York, Milan, } \\
\text { Paris }\end{array}$ & Closure of open spaces such as parks or waterfronts. \\
\hline 42 & Denver & Closure of parking space and allocation to pedestrians. \\
\hline 43 & $\begin{array}{c}\text { San Francisco, Montreal, } \\
\text { Oakland, } \\
\text { Portland, San Diego, } \\
\text { Seattle, Milan, Brussels, Douglas } \\
\text { (Isle of Man) }\end{array}$ & "Slow streets": reduced speed limits and closed streets for cars. \\
\hline 44 & $\begin{array}{l}\text { Chattanooga, Athens, } \\
\text { Hoboken }\end{array}$ & $\begin{array}{l}\text { Wider sidewalks (through the conversion of parking spots) for restaurants } \\
\text { and businesses. }\end{array}$ \\
\hline
\end{tabular}


Table A1. Cont.

\begin{tabular}{|c|c|c|}
\hline 45 & $\begin{array}{l}\text { City } \\
\text { Córdoba } \\
\text { Warsaw (only for health } \\
\text { workers) }\end{array}$ & $\begin{array}{l}\text { Measure Description } \\
\text { Free parking } 24 \mathrm{~h} \text { a day in the central area to avoid the concentration of people and free } \\
\text { circulation of vehicles. }\end{array}$ \\
\hline 46 & Kazan, San Francisco & Essential workers are allowed to make use of taxi services for free. \\
\hline 47 & Lagoa da Pampulha & $\begin{array}{l}\text { Restriction of the circulation of pedestrians and vehicles on the most-visited spots } \\
\text { in the city. }\end{array}$ \\
\hline 48 & $\begin{array}{l}\text { Denver, Mississauga, San Jose, } \\
\text { New York, Madison, Los } \\
\text { Angeles, Columbus, } \\
\text { Boulder, Annapolis }\end{array}$ & Suspension of the parking enforcement policy. \\
\hline 49 & Boston & Cancelation of parking tickets given to healthcare workers. \\
\hline 50 & Chicago & Subsidies for cab drivers and owners to make sure they can keep operating. \\
\hline 51 & $\begin{array}{l}\text { New York, Columbus, San } \\
\text { Francisco }\end{array}$ & Deemed bicycle shops essential businesses. \\
\hline 52 & Lima & Temporary suspension of the collection of tolls for health personnel. \\
\hline 53 & $\begin{array}{l}\text { Nice, Budapest, Manchester, } \\
\text { Madrid }\end{array}$ & Free public transport for medical workers. \\
\hline 54 & Taipei & Discounted Uber rides for medical professionals. \\
\hline 55 & Chicago & $\begin{array}{l}\text { Surveying the business community's ridership demands and support-related } \\
\text { planning efforts. }\end{array}$ \\
\hline 56 & Taipei & Quarantine Taxi Service for people in need of medical attention. \\
\hline 57 & Beijing & In-app metro reservation system. \\
\hline 58 & Gurugram & Buses transport passengers/travelers from the airport to quarantine locations. \\
\hline 59 & Gurugram, Barcelona & Buses transport medical teams and COVID-19 patients to and from hospitals. \\
\hline 60 & Hong Kong & $\begin{array}{c}\text { Use of a robot for deep cleaning and decontamination in train compartments } \\
\text { and stations. }\end{array}$ \\
\hline
\end{tabular}

\section{References}

1. Scott, M. Covid-19, Place-making and Health. Plan. Theory Pr. 2020, 21, 343-348. [CrossRef]

2. Karuri-Sebina, G.; Haegeman, K.-H.; Ratanawaraha, A. Urban futures: Anticipating a world of cities. Foresight 2016, 18, 449-453. [CrossRef]

3. Sharifi, A.; Khavarian-Garmsir, A.R. The COVID-19 pandemic: Impacts on cities and major lessons for urban planning, design, and management. Sci. Total. Environ. 2020, 749, 142391. [CrossRef]

4. Huang, J.; Wang, H.; Fan, M.; Zhuo, A.; Sun, Y.; Li, Y. Understanding the Impact of the COVID-19 Pandemic on TransportationRelated Behaviors with Human Mobility Data. In Proceedings of the 26th ACM SIGKDD International Conference on Knowledge Discovery \& Data Mining, Virtual Event, CA, USA, 23-27 August 2020; pp. 3443-3450.

5. Tirachini, A.; Cats, O. COVID-19 and Public Transportation: Current assessment, prospects and research needs. J. Public Transp. 2020, 22, 1-21. [CrossRef]

6. Lozzi, G.; Rodrigues, M.; Marcucci, E.; Teoh, T.; Gatta, V.; Pacelli, V. Research for TRAN Committee—COVID-19 and Urban Mobility: Impacts and Perspectives; European Parliament: Brussels, Belgium, 2020.

7. EIT. COVID-19: What is Happening in the Area of Urban Mobility. 2020. Available online: https://eit.europa.eu/news-events/ news / covid-19-what-happening-area-urban-mobility (accessed on 26 December 2020).

8. Papa, R.; Galderisi, A.; Vigo Majello, M.C.; Saretta, E. Smart and Resilient Cities. A Systemic Approach for Developing Cross-sectoral Strategies in the Face of Climate Change. TeMA J. Land Use Mobil. Environ. 2015, 8, 19-49. [CrossRef]

9. Baron, M. Do we need smart cities for resilience? J. Econ. Manag. 2012, 10, 32-46.

10. Deal, B.; Pan, H.; Pallathucheril, V.; Fulton, G. Urban Resilience and Planning Support Systems: The Need for Sentience. J. Urban Technol. 2017, 24, 29-45. [CrossRef]

11. Kakderi, C.; Psaltoglou, A.; Fellnhofer, K. Digital platforms and online applications for user engagement and collaborative innovation. In Proceedings of the 20th Scientific Conference, Association of Greek Regional Scientists, Regions at a turning point: Post-Digital communities, New regionalism and Re-nationalisation-Sustainable development implications, Athens, Greece, 22-23 June 2018; pp. 112-117. 
12. Komninos, N.; Panori, A.; Kakderi, C. Smart cities beyond algorithmic logic: Digital platforms, user engagement and data science. In Smart Cities in the Post-Algorithmic Era; Edward Elgar Publishing: Northampton, MA, USA, 2019.

13. Komninos, N.; Panori, A. The creation of city smartness: Architectures of intelligence in smart cities and smart ecosystems. In Smart Cities in the Post-Algorithmic Era; Edward Elgar Publishing: Northampton, MA, USA, 2019.

14. Kakderi, C.; Tasopoulou, A. Regional economic resilience: The role of national and regional policies. Eur. Plan. Stud. 2017, 25, 1435-1453. [CrossRef]

15. Batty, M.; Murcio, R.; Iacopini, I.; Vanhoof, M.; Milton, R. London in Lockdown: Mobility in the Pandemic City. arXiv, 2021; arXiv:2011.07165.

16. Kraemer, M.U.; Yang, C.H.; Gutierrez, B.; Wu, C.H.; Klein, B.; Pigott, D.M.; Scarpino, S.V. The effect of human mobility and control measures on the COVID-19 epidemic in China. Science 2020, 368, 493-497. [CrossRef]

17. Global Footprint Network. Earth Overshoot Day. 2020. Available online: https://www.footprintnetwork.org/our-work/earthovershoot-day/ (accessed on 5 April 2021).

18. Lai, K.Y.; Webster, C.; Kumari, S.; Sarkar, C. The nature of cities and the Covid-19 pandemic. Curr. Opin. Environ. Sustain. 2020 46, 27-31. [CrossRef]

19. Kakderi, C.; Komninos, N.; Panori, A.; Oikonomaki, E. Next City: Learning from Cities During COVID-19 to Tackle Climate Change. Sustainability 2021, 16, 3158. [CrossRef]

20. OECD. Tackling Coronavirus (COVID-19): Contributing to a Global Effort. Cities Policy Responses. 2020. Available online: https: / / read.oecd-ilibrary.org/view / ?ref=126_126769-yen45847kf\&title=Coronavirus-COVID-19-Cities-Policy-Responses (accessed on 8 October 2020).

21. UN Habitat. Cities and Pandemics: Towards a More Just, Green and Healthy Future. United Nations Human Settlements Programme. 2021. Available online: https:/ / unhabitat.org/sites/default/files/2021/03/cities_and_pandemics-towards_a_more_just_green_ and_healthy_future_un-habitat_2021.pdf (accessed on 20 November 2020).

22. Chamings, A. The 2020 San Francisco Exodus is Real, and Historic, Report Shows; SF Gate: San Francisco, CA, USA, 2020.

23. Bozzon, A.; Psyllidis, A. Social Distancing Dashboard, TU Delft 25 May. 2020. Available online: https://www.tudelft.nl/covid/ social-distancing/social-distancing-dashboard (accessed on 3 March 2021).

24. Pozoukidou, G.; Chatziyiannaki, Z. 15-Minute City: Decomposing the New Urban Planning Eutopia. Sustainability 2021, 13, 928. [CrossRef]

25. Komninos, N. The New Logic of Environmental Sustainability under the Smart Everything Paradigm; ERSA: Thessaloniki, Greece, 2020.

26. Ye, L.; Mandpe, S.; Meyer, P.B. What is smart growth?-Really? J. Plan. Lit. 2005, 19, 301-315. [CrossRef]

27. Venter, Z.S.; Barton, D.N.; Gundersen, V.; Figari, H.; Nowell, M. Urban nature in a time of crisis: Recreational use of green space increases during the COVID-19 outbreak in Oslo, Norway. Environ. Res. Lett. 2020, 15, 104075. [CrossRef]

28. Xie, J.; Luo, S.; Furuya, K.; Sun, D. Urban parks as green buffers during the COVID-19 pandemic. Sustainability 2020, 12, 6751. [CrossRef]

29. Ugolini, F.; Massetti, L.; Calaza-Martínez, P.; Cariñanos, P.; Dobbs, C.; Ostoić, S.K.; Sanesi, G. Effects of the COVID-19 pandemic on the use and perceptions of urban green space: An international exploratory study. Urban For. Urban Green. 2020, $56,1268$. [CrossRef] [PubMed]

30. Honey-Rosés, J.; Anguelovski, I.; Chireh, V.; Daher, K.; Konijnendijk, C.; van den Bosch, C.; Litt, J.S.; Nieuwenhuijsen, M.J. The impact of COVID-19 on public space: An early review of the emerging questions-design, perceptions and inequities. Cities Health 2020, 1-17. [CrossRef]

31. Batty, M. The Morphology of the Post Pandemic City. UCL Working Paper Series, Paper 226. 2020. Available online: https:/ / www.ucl.ac.uk/bartlett/casa/publications/2021/mar/casa-working-paper-226-morphology-post-pandemic-cityapplications-london (accessed on 5 April 2021).

32. Moovit Public Transport Index (2020). Available online: https://moovitapp.com/insights/en/Moovit_Insights_Public_Transit_ Index-countries (accessed on 8 October 2020).

33. Basu, R.; Ferreira, J. Sustainable mobility in auto-dominated Metro Boston: Challenges and opportunities post-COVID-19. Transp Policy 2021, 103, 197-210. [CrossRef]

34. Vickerman, R. Will Covid-19 put the public back in public transport? A UK perspective. Transp. Policy 2021, 103, 95-102. [CrossRef] [PubMed]

35. Bernhard, A. The Great Bicycle Boom of 2020, BBC. 2020. Available online: https://www.bbc.com/future/bespoke/made-onearth/the-great-bicycle-boom-of-2020.html (accessed on 28 January 2021).

36. Reid, C. Bike Sales Increased 63\% During Lockdown, Reveals U.K.'s Bicycle Association. Forbes. 3 August 2020. Available online: https: / www.forbes.com/sites/carltonreid/2020/08/03/bike-sales-increased-63-during-lockdown-reveals-uks-bicycleassociation/\#7ce2d3907e12 (accessed on 8 October 2020).

37. Cosnard, D. L'usage du vélo en forte expansion dans les grandes villes. Le Monde. 4 September 2020. Available online: https: / / www.lemonde.fr/politique/article/2020/09/04/1-usage-du-velo-en-forte-expansion-dans-les-grandes-villes_605094 3_823448.html (accessed on 5 September 2020).

38. Vandi, K. Coronavirus: How Pandemic Sparked European Cycling Revolution. BBC News. 2020. Available online: https: / / www.bbc.com/news/world-europe-54353914 (accessed on 8 October 2020). 
39. European Commission. The European Green Deal. 2019. Available online: https://ec.europa.eu/info/strategy/priorities-2019-2 024/european-green-deal_en (accessed on 30 August 2020).

40. Mock, B. A Green Stimulus Plan for a Post-Coronavirus Economy; Bloomberg CityLab: New York, NY, USA, 2020.

41. Kanda, W.; Kivimaa, P. What opportunities could the COVID-19 outbreak offer for sustainability transitions research on electricity and mobility? Energy Res. Soc. Sci. 2020, 68, 101666. [CrossRef] [PubMed]

42. Hausler, S.; Heineke, K.; Hensley, R.; Möller, T. Our Insights, The Impact of COVID 19 in New Mobility Solutions. 2020. Available online: https:/ / www.mckinsey.com/industries/automotive-and-as (accessed on 8 October 2020).

43. Gkiotsalitis, K.; Cats, O. Public transport planning adaption under the COVID-19 pandemic crisis: Literature review of research needs and directions. Transp. Rev. 2021, 41,1-19. [CrossRef]

44. Budd, L.; Ison, S. Responsible Transport: A post-COVID agenda for transport policy and practice. Transp. Res. Interdiscip. Perspect. 2020, 6, 100151. [CrossRef]

45. Gutiérrez, A.; Miravet, D.; Domènech, A. COVID-19 and urban public transport services: Emerging challenges and research agenda. Cities Health 2020, 1-7. [CrossRef]

46. James, P.; Das, R.; Jalosinska, A.; Smith, L. Smart cities and a data-driven response to COVID-19. Dialogues Hum. Geography. 2020, 10, 255-259. [CrossRef]

47. Litman, T. Evaluating Complete Streets; Victoria Transport Policy Institute: Victoria, BC, Canada, 2015.

48. Carlson, S.A.; Paul, P.; Kumar, G.; Watson, K.B.; Atherton, E.; Fulton, J.E. Prevalence of Complete Streets policies in US municipalities. J. Transp. Health 2017, 5, 142-150. [CrossRef]

49. Komninos, N. Smart Cities and Connected Intelligence: Platforms, Ecosystems and Network Effects; Routledge: Abingdon, UK, 2017.

50. Komninos, N.; Kakderi, C. Smart Cities in the Post-Algorithmic Era: Integrating Technologies, Platforms and Governance; Edward Elgar Publishing: Northampton, MA, USA, 2019.

51. OECD. The Territorial Impact of Covid-19: Managing the Crisis across Levels of Government. Available online: https: / / read.oecd-ilibrary.org/view / ?ref=128_128287-5agkkojaaa\&title=The-territorial-impact-of-covid-19-managing-the-crisisacross-levels-of-government (accessed on 30 November 2020).

52. Vermicelli, S.; Cricelli, L.; Grimaldi, M. How can crowdsourcing help tackle the COVID-19 pandemic? An explorative overview of innovative collaborative practices. RED Manag. 2021, 51, 183-194.

53. Panori, A.; Kakderi, C.; Komninos, N.; Fellnhofer, K.; Reid, A.; Mora, L. Smart systems of innovation for smart places: Challenges in deploying digital platforms for co-creation and data-intelligence. Land Use Policy 2020, 104631. [CrossRef]

54. Bragazzi, N.L.; Dai, H.; Damiani, G.; Behzadifar, M.; Martini, M.; Wu, J. How big data and artificial intelligence can help better manage the COVID-19 pandemic. Int. J. Environ. Res. Public Health 2020, 17, 3176. [CrossRef] [PubMed]

55. Government Technology Platform. Pandemic Acts as Trial Run for Many Emerging Technologies. Available online: https://www. governing.com/security / Pandemic-Acts-as-Trial-Run-for-Many-Emerging-Technologies.html (accessed on 8 October 2020).

56. Alam, F.; Almaghthawi, A.; Katib, I.; Albeshri, A.; Mehmood, R. iResponse: An AI and IoT-Enabled Framework for Autonomous COVID-19 Pandemic Management. Sustainability 2021, 13, 3797. [CrossRef]

57. Cugurullo, F. Urban artificial intelligence: From automation to autonomy in the smart city. Front. Sustain. Cities 2020, 2, 1-14. [CrossRef]

58. Costa, D.G.; Peixoto, J.P.J. COVID-19 pandemic: A review of smart cities initiatives to face new outbreaks. IET Smart Cities 2020, 2, 64-73. [CrossRef]

59. Abduljabbar, R.; Dia, H.; Liyanage, S.; Bagloee, S.A. Applications of artificial intelligence in transport: An overview. Sustainability 2019, 11, 189. [CrossRef]

60. Yigitcanlar, T.; Cugurullo, F. The sustainability of artificial intelligence: An urbanistic viewpoint from the lens of smart and sustainable cities. Sustainability 2020, 12, 8548. [CrossRef]

61. Mora, L.; Wu, X.; Panori, A. Mind the gap: Developments in autonomous driving research and the sustainability challenge. J. Clean. Prod. 2020, 275, 124087. [CrossRef]

62. Yigitcanlar, T.; Desouza, K.; Butler, L.; Roozkhosh, F. Contributions and risks of artificial intelligence (AI) in building smarter cities: Insights from a systematic review of the literature. Energies 2020, 13, 1473. [CrossRef]

63. Kandt, J.; Batty, M. Smart cities, big data and urban policy: Towards urban analytics for the long run. Cities 2021, 109, 102992. [CrossRef]

64. Komninos, N.; Kakderi, C.; Collado, A.; Papadaki, I.; Panori, A. Digital Transformation of City Ecosystems: Platforms Shaping Engagement and Externalities across Vertical Markets. J. Urban Technol. 2021, 28, 93-114. [CrossRef]

65. Smith, K.B. Typologies, Taxonomies, and the Benefits of Policy Classification. Policy Stud. J. 2002, 30, 379-395. [CrossRef]

66. Burau, V.; Blank, R.H. Comparing health policy: An assessment of typologies of health systems. J. Comp. Policy Anal. Res. Pr. 2006, 8, 63-76. [CrossRef]

67. NACTO. Global Designing Cities Initiative. Streets for Pandemic Response and Recovery. 2020. Available online: https://nacto.org/ wp-content/uploads/2020/09/Streets_for_Pandemic_Response_Recovery_Full_20-09-24.pdf (accessed on 15 September 2020).

68. WBCSD. Methodology and indicator calculation method for Sustainable Urban Mobility, Sustainable Mobility Project 2.0 (SMP2.0) Indicators Work Stream, World Business Council for Sustainable Development. 2020. Available online: http://docs.wbcsd.org/ 2015/03/Mobility_indicators.pdf (accessed on 30 March 2020). 
69. European Commission. A Concept for Sustainable Urban Mobility Plans. 2013. Available online: https://eur-lex.europa.eu/ resource.html?uri=cellar:82155e82-67ca-11e3-a7e4-01aa75ed71a1.0011.02/DOC_4\&format=PDF (accessed on 30 March 2020).

70. Komninos, N.; Kakderi, C.; Mora, L.; Panori, A.; Sefertzi, E. Towards High Impact Smart Cities: A Universal Architecture Based on Connected Intelligence Spaces. J. Knowl. Econ. 2021. [CrossRef]

71. Howlett, M. Procedural Policy Tools and the Temporal Dimensions of Policy Design. Int. Rev. Public Policy 2019, 1, 27-45. [CrossRef]

72. Laker, L. Milan Announces Ambitious Scheme to Reduce Car Use after Lockdown. The Guardian. 2020. Available online: https:/ / www.theguardian.com/world/2020/apr/21/milan-seeks-to-prevent-post-crisis-return-of-traffic-pollution?fbclid= IwAR1G_svSB3fjoi_E031PLts_UHkk3n78PoBW62Crv_-XtYsFY_27Nmw_Fhc (accessed on 8 October 2020).

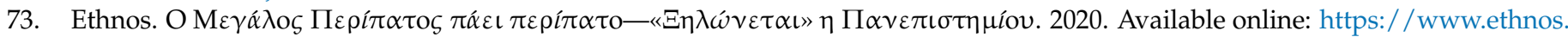
gr/ellada/125198_o-megalos-peripatos-paei-peripato-xilonetai-i-panepistimioy (accessed on 8 October 2020). 